\title{
HUBUNGAN ANTARA PERUBAHAN ORGANISASI, BUDAYA ORGANISASI, KEPEMIMPINAN TRANSFORMASIONAL, DAN KINERJA KARYAWAN PADA PT PANCAPUTRA MITRATAMA MANDIRI
}

\author{
Safira Shabrina \\ Universitas Negeri Surabaya \\ safirashabrina16080574145@mhs.unesa.ac.id
}

\begin{abstract}
This research tries to find the relationship between organizational change, organizational culture, transformational leadership, and employee performance at PT Pancaputra Mitratama Mandiri. This research is using a quantitative approach. The population in this study are 32 employees at PT Pancaputra Mitratama Mandiri. Data are running using software SmartPLS, which uses SEM and PLS. The results in this research are (1) Transformational leadership has an insignificant impact on employee performance, (2) transformational leadership has a significant impact on organizational change, (3) transformational leadership has a significant impact on organizational culture, (4) organizational change has an insignificant impact on employee performance, (5) organizational culture has an insignificant impact on employee performance, (6) organizational change has a significant impact on organizational culture, (7) transformational leadership on employee performance has not indirect impact by organizational culture, (8) transformational leadership on employee performance has not indirect impact by organizational change, and (9) organizational change on employee performance has not indirect impact by organizational culture.
\end{abstract}

Keywords: organizational change; organizational culture; employee performance; transformational leadership.

\section{PENDAHULUAN}

Organisasi dituntut mampu menyesuaikan stituasi dan kondisi perkembangan teknologi dan informasi agar mampu meraih tujuan organisasi secara ekonomis. Organisasi yang tak mampu beradaptasi cenderung stagnan dalam hal perkembangannya dan tidak kuat bersaing dengan perusahaan lainnya karena tidak adanya peningkatan kualitas dan kuantitas organisasi. Meningkatkan efektivitas organisasi untuk mengusahakan perbaikan kompetensi organisasi dalam penyesuaian diri terhadap perubahan lingkungan serta perubahan sikap anggota organisasi adalah dasar tujuan perusahaan melakukan perubahan (Robbins dan Judge, 2015:413). Organisasi perlu mempertimbangkan faktorfaktor yang dapat memengaruhi kinerja karyawan, salah satunya adalah perubahan organisasi. Karena perubahan lingkungan yang tidak bisa dihindarkan, sehingga penting bagi organisasi untuk mengerti bagaimana perubahan organisasi mampu membawa pengaruh terhadap kinerja (Wanza dan Nkuraru, 2016).

Mengingat perlunya upaya perusahaan untuk berubah di lingkungan yang dinamis, maka perubahan perlu untuk dirancang dan dikelola oleh pemimpin yang cerdas, visioner, dan kuat (Utami, 2007). Perubahan yang dibawa oleh pemimpin dapat menentukan apakah perusahaan dapat maju lebih baik atau malah mengalami kemunduran. Kepemimpinan adalah kemampuan memengaruhi kelompok agar dapat mencapai suatu sasaran (Robbins dan Judge, 2015:249). Pemimpin perlu membangun motivasi dan iklim kerja yang suportif dan kondusif sehingga kinerja dari karyawan dapat meningkat, maka pemimpin perlu mempertimbangkan tentang gaya kepemimpinannya. Kepemimpinan dapat memengaruhi kinerja karyawan, semakin bagus kepemimpinannya maka semakin baik kinerja bawahannya (Kurniawan, 2018).

Kinerja karyawan dipengaruhi oleh beberapa faktor, tidak hanya perubahan organisasi melainkan budaya organisasi. Bukan tentang seberapa kadar cinta karyawan terhadap budaya organisasinya atau sebaliknya, namun bagaimana karyawan memahami ciri-ciri budaya di organisasinya (Ismail, 2017). Salah satu cara agar tujuan organisasi dapat tercapai adalah melalui budaya organisasinya. Hal ini dikarenakan budaya yang diterapkan mampu memperbaiki sikap individu untuk meraih kreativitas 
Safira Shabrina. Hubungan antara Perubahan Organisasi, Budaya Organisasi, Kepemimpinan Transformasional, dan Kinerja Karyawan pada PT Pancaputra Mitratama Mandiri

kerja. Selain itu budaya yang didasari oleh nilai ini mampu memberikan motivasi terhadap karyawan dan berpengaruh terhadap kinerjanya (Utami et. al., 2017).

Fenomena perubahan organisasi banyak diterapkan oleh perusahaan demi kuat bersaing dalam dunia industri, salah satu perusahaan itu adalah PT Pancaputra Mitratama Mandiri. PT Pancaputra Mitratama Mandiri adalah distributor resmi dari perusahaan besar PT Shell Indonesia yang memasarkan fokus pada produk pelumas Shell. Berdasarkan observasi dan wawancara awal dengan karyawan PT Pancaputra Mitratama Mandiri, perubahan telah diterapkan di dalam organisasi. Contohnya adalah perubahan struktur organisasi yaitu penambahan divisi dan perubahan budaya. Penambahan divisi ini sekaligus perubahan dalam kepemimpinan di PT Pancaputra Mitratama Mandiri karena vice president yang sebelumnya tidak ada, kini ikut ambil alih keputusan terkait perusahaan. Selain itu, adanya divisi baru yaitu business analysist membawa perubahan dalam kinerja tim sales karena tugasnya yang menjadi pengingat weekly report agar tim sales dapat melaporkan tepat waktu. Selain itu, divisi baru ini juga menjadi pengamat bisnis, bagaimana prospek pelanggan, bagaimana cara agar target mampu terpenuhi, dan memberikan rekomendasi strategi untuk meningkatkan penjualan.

Perubahan budaya di PT Pancaputra Mitratama Mandiri adalah penerapan budaya yang sebelumnya belum ada contohnya berdoa bersama setiap pagi sebelum kegiatan dimulai, briefing meeting tim sales setiap pagi untuk mendiskusikan kendala yang ada sekaligus solusi yang dapat disampaikan dan absensi menggunakan teknologi finger print agar lebih valid. Banyaknya perubahan yang terjadi di PT Pancaputra Mitratama Mandiri tidak akan terlaksana tanpa keputusan pemimpin yang dapat dikategorikan sebagai kepemimpinan transformasional. Hasil wawancara dan observasi menunjukkan bahwa perubahan, budaya yang baru, dan gaya kepemimpinan yang baik ini tidak terlalu berpengaruh terhadap kinerja karyawan PT Pancaputra Mitratama Mandiri, atau dalam kata lain stagnan saja dan tidak mengalami kenaikan yang signifikan seperti sebelum perubahan dilakukan.

Tujuan penelitian ini menganalisis hubungan antara kepemimpinan transformasional sebagai variabel eksogen terhadap variabel perubahan organisasi, budaya organisasi, dan kinerja karyawan pada PT Pancapura Mitratama Mandiri sebagai variabel endogen.

\section{KAJIAN PUSTAKA DAN PENGEMBANGAN HIPOTESIS}

\section{Kinerja Karyawan}

Kinerja karyawan mengacu pada prestasi seseorang yang diukur berdasarkan standar dan kriteria yang ditetapkan oleh perusahaan (Yusthisia, 2019). Kinerja merupakan hasil kerja seorang karyawan selama periode tertentu dibandingkan dengan berbagai kemungkinan misalnya standar, sasaran atau kriteria yang telah ditentukan terlebih dahulu dan disepakati bersama (Sunaryo, 2017). Kinerja adalah suatu fungsi dari motivasi dan kemampuan. Untuk menyelesaikan tugas atau pekerjaan seseorang sepatutnya memiliki derajat kesediaan dan tingkat kemampuan tertentu (Rifai dalam Akbar dan Boseren, 2016).

Rahman dan Kistyanto (2019) menjelaskan indikator kinerja karyawan adalah (1) kuantitas dari hasil, yaitu jumlah tingkat kegiatan yang telah dihasilkan oleh karyawan. (2) kualitas dari hasil, yaitu tingkat baik dan buruknya atau taraf dari suatu hasil pekerjaan yang telah dilakukan. (3) Ketepatan waktu dari hasil, suatu persepsi seorang karyawan pada tingkat estimasi aktivitas yang telah diselesaikan mulai awal hingga tercipta sebuah hasil. (4) Kehadiran di tempat kerja, adalah tingkat gairah kehadiran beserta tepat waktu atau tidaknya seseorang terhadap jadwal kerja yang ditetapkan.

\section{Perubahan Organisasi}

Perubahan organisasi perlu direncanakan sebagai pengembangan organisasi yang dilakukan untuk meraih sasaran organisasi. Tujuannya, untuk memperbaiki kemampuan organisasi untuk beradaptasi dengan perubahan lingkungan dan perilaku karyawan (Priyono et. al., 2018). Perubahan di organisasi mengarah pada kesepakatan bahwa mengelola organisasi pada jaman modern seperti sekarang tidak mungkin lagi hanya mengandalkan kepada teknik konvensional seperti struktur mekanistik maupun 
jalur perintah yang panjang dan rumit (Sunaryo, 2017). Organisasi perlu memastikan bahwa strategi perubahannya layak, implemestasi perubahan organisasi secara kelanjutan akan menjadi norma di tempat kerja, memastikan kesempatan untuk pertumbuhan dan pengembangan organisasi (Methode et. al., 2019).

Indikator perubahan organisasi menurut Methode et. al. (2019) adalah sebagai berikut. (1) Perubahan struktural meliputi hierarki yang ada dalam organisasi, rantai komando, sistem manajemen, dan prosedur administratif. (2) Perubahan strategik, perubahan strategik dalam perubahan adalah perubahan yang berisi strategi perusahaan dalam hal keunggulan kompetitif, ruang lingkup, penyebarang sumber daya, dan sinergi. (3) Perubahan teknologi, perubahan tekologi adalah peningkatan efisiensi suatu produk atau proses yang menghasilkan peningkatan output, tanpa meningkatkan input.

\section{Budaya Organisasi}

Budaya organisasi merupakan suatu persepsi bersama yang dianut oleh semua anggota organisasi (Sunaryo, 2017). Budaya organisasi berperan penting dalam pencapaian suatu tujuan organisasi karena budaya organisasi merupakan suatu cara bermutu dan didasari oleh nilai yang penuh makna, dan memberikan motivasi serta inspirasi untuk bekerja lebih baik (Utami et. al., 2017). Tingkat kebersamaan yang tinggi menciptakan iklim internal yang baik, hal ini mengindikasikan bahwa budaya kuat dan merupakan pengaruh yang besar terhadap budaya organisasi. (Robbins dan Judge dalam Sagita et. al., 2018).

Denison dan Mishra (1995) mengembangkan indikator budaya organisasi diantaranya adalah: (1) keterlibatan, yaitu sejauh mana inovasi dan pengambilan keputusan resiko oleh karyawan dapat dilakukan (2) konsistensi, yaitu sejauh mana perhatian terhadap hal rini, presisi (kecermatan), dan analisis oleh karyawan dapat dilakukan. (3) adaptabilitas, adalah sejauh mana fokus kepada hasil lebih besar dari pada metode dan praktek yang digunakan untuk menjangkau hasil tersebut dilakukan oleh organisasi. (4) misi, adalah sejauh mana efek dari hasil ketepatan keputusan pimpinan dipertimbangkan terhadap anggota di organisasi.

\section{Kepemimpinan Transformasional}

Kepemimpinan transformasional adalah pemimpin yang memiliki kemampuan memengaruhi yang mengagumkan dan memberikan inspirasi pengikutnya dan mampu meninggalkan kepentingan pribadinya demi keuntungan organisasi. (Robbins dan Judge, 2015:262). Kepemimpinan transformasional memiliki dampak yang melebihi kepemimpinan transaksional, yaitu mengilhami dan memotivasi anak buah untuk berbuat lebih dari yang diharapkan. Indikator langsung dari adanya kepemimpinan transformational ini terletak pada perilaku para pengikutnya yang didasarkan pada persepsi mereka terhadap sang pemimpin (Riyono, 2015). Kepemimpimpinan transformasional meliputi hubungan yang lebih intens antara pemimpin dan karyawannya. Kepemimpinan transformasional memperlihatkan pemimpin yang memberikan perhatian individual dengan memberikan tugas yang sesuai dengan kemampuan karyawan, serta mampu menerapkan stimulasi intelektual kepada karyawannya seperti bagaimana cara untuk menganalisis suatu situasi dan cara agar karyawan kreatif dalam mengembangkannya (Septyan et. al., 2017).

Bass dan Avolio dalam Antonakis (2012) telah mengembangkan indikator kepemimpinan transformasional yaitu sebagai berikut. (1) Karismatik, karismatik atau idealized influenced menurut Bass adalah komponen emosional dalam kepemimpinan yang biasanya mendeskripsikan kekuatan dari pemimpin mampu memberikan dampak yang hebat bagi pengikutnya. (2) Motivasi yang menginspirasi, inspirational motivating adalah kepemimpinan yang menginspirasi dan memotivasi pengikut untuk meraih tujuan yang sebelumnya nampak mustahil untuk berhasil. Disini, pemimpin meningkatkan ekspektasi pengikut dan menginspirasinya dengan berkomunikasi secara percaya diri bahwa organisasi mampu mencapai tujuan bersama. (3) Stimulasi intelektual adalah pemimpin mendorong kecerdasan pengikutnya dengan menciptakan "problem awareness dan problem solving". Karena karyawan diikut sertakan dalam proses penyelesaian masalah, maka karyawan termotivasi 
Safira Shabrina. Hubungan antara Perubahan Organisasi, Budaya Organisasi, Kepemimpinan Transformasional, dan Kinerja Karyawan pada PT Pancaputra Mitratama Mandiri

untuk mampu menyelesaikan permasalahan yang ada. (4) Konsiderasi individu yaitu pemimpin dalam penerapan konsiderasi individu memberikan perhatian secara individu dan berorientasikan mentoring terhadap pengikut. Tujuan yang ingin diraih adalah coaching dan konseling untuk pengikut, mempertahankan kontak bersama-sama, dan membantu pengikut untuk aktualisasi diri.

\section{Hubungan antar Variabel}

Langkah yang diterapkan organisasi dalam pencapaian tujuan hendaklah perlu menggerakkan bawahannya untuk dapat meningkatkan kinerjanya. Artinya, semakin bagus kepemimpinan seorang pemimpin kepada karyawannya, maka semakin baik pula hasil kerja karyawannya (Kurniawan, 2018).

Kinerja karyawan merupakan faktor penentu keberhasilan suatu perusahaan. Untuk itu, kinerja karyawan harus mendapat perhatian dari para pimpinan perusahaan, pemimpin yang baik harus mampu memengaruhi karyawan agar dapat melakukan pekerjaan sesuai dengan konsep yang telah ditentukan (Septyan et. al., 2017).

Adanya dampak kepemimpinan terhadap kinerja karyawan dibuktikan penelitian dari Akbar dan Boseren (2016) yang menyatakan kepemimpinan memengaruhi kinerja karyawan Balai Laboratorium Kesehatan Papua secara signifikan positif. Penelitian ini diperkuat lagi oleh Kurniawan (2018) yang hasilnya adalah adanya pengaruh signifikan positif antara gaya kepemimpinan terhadap kinerja karyawan Percetakan Dimas di kota Palembang.

H1: Kepemimpinan transformasional berpengaruh signifikan positif terhadap kinerja karyawan PT Pancaputra Mitratama Mandiri.

Pemimpin yang tidak berubah dan berkembang ke haluan yang lebih baik terlebih dahulu tidak akan mampu merubah perusahannya atau organisasinya. Organisasi tak akan mampu maju dalam persaingan industri hingga pemimpinnya maju di dalam organisasinya terlebih dulu. Jika segenap jajaran pemimpin beralih ke arah yang lebih baik, maka perkembangan organisasi akan berjalan secara langsung. Pemimpin yang tidak efektif seperti menggambarkan organisasi yang rentan. Pemimpin yang ulet sama dengan organisasi yang kuat. Segalanya yang terjadi pada organisasi akan berubah, sesuai dengan ketangguhan dan kegigihan kepemimpinan pimpinannya (Utami, 2007).

Teori ini didukung oleh jurnal dari Utami (2007) yang menyatakan pemimpin dengan kepemimpinan yang bertahan kekuasannya maupun karakternya dan kewajibannya adalah salah satu kebutuhan dari proses perubahan. Keyakinannya, kepercayaan diri, dan keterlibatan yang maksimal harus dimiliki oleh pemimpin agar mampu menghadapi kompleksitas permasalah dan hambatan yang ada. Diperkuat lagi oleh teori dari İkinci (2014) yang menyiratkan kepemimpinan transformasional sebagai kepemimpinan yang paling banyak diadopsi terutama beberapa tahun terakhir karena keberhasilannya dalam proses perubahan organisasi.

$\mathrm{H} 2$ : Kepemimpinan transformasional berpengaruh signifikan positif terhadap perubahan organisasi di PT Pancaputra Mitratama Mandiri.

Budaya organisasi dibangun dan dipertahankan ditunjukan dalam ideologi pemimpinnya. Selanjutnya, tolok ukur yang digunakan dalam mempekerjakan karyawan sangat memengaruhi budaya di organisasi. Aksi pemimpin sangat berdampak terhadap tindakan yang dapat diterima oleh pegawai (Robbins dalam Kristanti, 2011).

Penelitian dari Gholamzadeh et. al., (2014) menjelaskan bahwa gaya kepemimpinan transformasional dan transaksional memengaruhi budaya di Mapsa Company secara signifikan positif. Penelitian lainnya yang memperkuat teori ini adalah Kartini dan Rustanto (2018) yang hasil pengujiannya menunjukkan bahwa kepemimpinan memberikan dampak signifikan positif terhadap budaya organisasi di Politeknik LP3I Jakarta Kampus. 
H3: Kepemimpinan transformasional berpengaruh signifikan positif terhadap budaya organisasi PT Pancaputra Mitratama Mandiri.

Menciptakan metode baru yang perlu diperbaiki dengan memanfaatkan sarana yang ada dalam bentuk untuk pertumbuhan mutu, keampuhan dan tanggung jawab organisasi terhadap pemangku kepentingan merupakan tujuan organisasi melakukan perubahan. Artinya, upaya meningkatkan atau memperbaiki kinerja karyawan adalah salah satu metode perusahaan melakukan perubahan agar menjadi lebih baik dari keadaan sebelumnya. (Poluakan, 2016).

Penelitian terdahulu kedua variabel ini telah diteliti oleh Utami et. al. (2017) yang mengungkapkan hasil penelitian perubahan organisasi terhadap kinerja karyawan berpengaruh secara signifikan positif. Diperkuat oleh penelitian dari Poluakan (2016) yang menunjukkan hasil penelitiannya yaitu perubahan organisasi berpengaruh signifikan positif terhadap kinerja karyawan PT Galesong Prima Manado.

H4: Perubahan organisasi berpengaruh signifikan positif terhadap kinerja karyawan PT Pancaputra Mitratama Mandiri.

Maksud dari perusahaan menerapkan budaya organisasi salah satunya adalah meraih sasaran organisasi dengan mempraktikkan peraturan dan gelora kerja yang menjadikan karyawan berkinerja dengan baik. Nama baik yang dipegang oleh perusahaan atau organisasi dapat terlihat dari perilaku dan performa yang ditunjukkan oleh karyawannya (Utami et. al., 2017).

Sagita et. al. (2018) menyatakan dalam jurnalnya budaya organisasi yang baik mampu secara signifikan meningkatkan kinerja karyawan. Penelitian lainnya yang memperkuat teori ini adalah penelitian dari Ismail (2017) yang membuktikan bahwa budaya organisasi memengaruhi kinerja karyawan secara signifikan positif.

H5: Budaya organisasi berpengaruh signifikan terhadap kinerja karyawan PT Pancaputra Mitratama Mandiri.

Salah satu prospek vital dalam perubahan organisasi adalah pembentukan budaya organisasi yang sesuai dengan arah dan tujuan reformasi birokrasi sehingga mampu membawa pada perubahan sikap dan perilaku kerja karyawan. Perubahan di organisasi pada dasarnya meningkatkan efektiftas organisasi, hal ini dapat menyebabkan perubahan lingkungan serta perubahan tindakan orang-orang yang ada dalam organisasi. Maka, pada organisasi akan menyebabkan perubahan budaya organisasi (Fahrudin et. al., 2019). Fahrudin et. al. (2019) menjabarkan hasil pengujiannya bahwa perubahan organisasi berpengaruh signifikan positif terhadap budaya organisasi.

H6: Perubahan organisasi berpengaruh signifikan positif terhadap budaya organisasi PT Pancaputra Mitratama Mandiri.

Apabila pemimpin berhasil memengaruhi karyawannya dengan visi, menanamkan karismanya, memotivasi dan menjadi inspirator, menstimulasi intelektual, kreatifitas dan menghargai karyawannya maka dapat dipastikan karyawan akan bekerja dengan baik, sungguh-sungguh dan loyal pada perusahaan sehingga kinerjanya meningkat (Robbins dalam Septyan et. al., 2017). Penelitian Septyan et. al. (2017) ini menjelaskan bahwa kepemimpinan transformasional memengaruhi kinerja karyawan CV. Jade Indopratama Malang.

Upaya untuk meningkatkan kinerja pegawai yang bekerja pada Balai Laboratorium Kesehatan Papua tergantung pada budaya organisasi yang diterapkan pada Balai Laboratorium Kesehatan Papua, budaya organisasi juga sangat berarti dan memberikan dampak yang signifikan terhadap kinerja (Akbar dan Boseren, 2016). Dari penjelasan hubungan antara kepemimpinan transformasional dan 
Safira Shabrina. Hubungan antara Perubahan Organisasi, Budaya Organisasi, Kepemimpinan Transformasional, dan Kinerja Karyawan pada PT Pancaputra Mitratama Mandiri

budaya organisasi terhadap kinerja karyawan ini, ada indikasi bahwa budaya organisasi memediasi kepemimpinan transformasional terhadap kinerja karyawan.

H7: Kepemimpinan transformasional berpengaruh signifikan positif terhadap kinerja karyawan melalui budaya organisasi PT Pancaputra Mitratama Mandiri.

Kinerja pegawai tidak dapat dilepaskan dari peran pemimpinnya. Seorang pemimpin mempunyai tanggung jawab untuk melaksanakan tugas dan perannya sangat penting dalam keberhasilan organisasi yang dipimpinnya (Raharjo dan Nafisah, 2006). Perubahan organisasi bertujuan agar organisasi tidak menjadi statis dengan kemajuan teknologi. Tujuan utama dari terjadinya perubahan adalah untuk meningkatkan kemampuan organisasi, salah satunya adalah kinerja (Sunaryo, 2017). Maka, perubahan organisasi memiliki indikasi memediasi kepemimpinan transformasional terhadap kinerja karyawan.

H8: Kepemimpinan transformasional berpengaruh signifikan positif terhadap kinerja karyawan melalui perubahan organisasi PT Pancaputra Mitratama Mandiri.

Perusahaan dalam meraih keberhasilan dalam mengelola perubahan organisasi harus mengarah pada peningkatan kemampuan dalam menghadapi tantangan dan peluang yang timbul. Selain perubahan organisasi, budaya juga memengaruhi kinerja karyawan. Dengan adanya budaya organisasi organisasi dapat mengubah sikap dan perilaku individu untuk mencapai suatu produktivitas kerja, karena tujuan budaya organisasi adalah untuk menciptakan disiplin dan meningkatkan semangat kerja. Maka, budaya organisasi memiliki indikasi memediasi perubahan organisasi terhadap kinerja karyawan (Utami et. al., 2017).

H9: Perubahan organisasi berpengaruh signifikan positif terhadap kinerja karyawan melalui budaya organisasi PT Pancaputra Mitratama Mandiri.

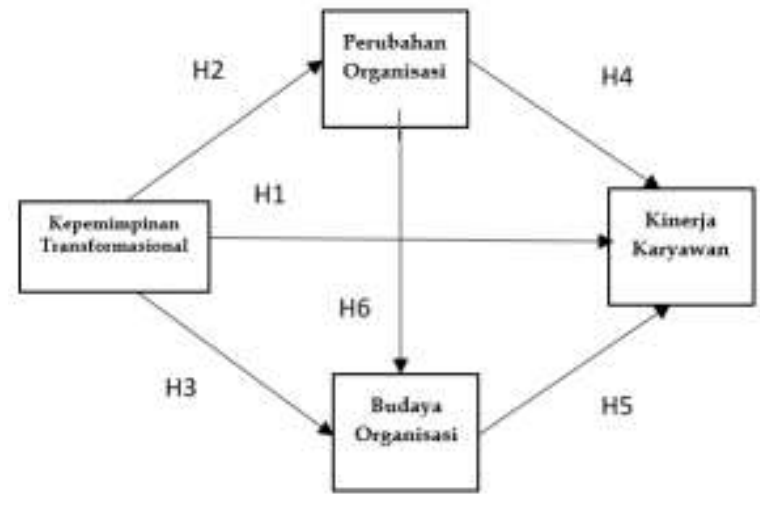

Gambar 1. KERANGKA KONSEPTUAL

\section{METODE PENELITIAN}

Penelitian ini merupakan penelitian kausalitas yang menganalisis hubungan antara perubahan organisasi, budaya organisasi, kepemimpinan transformasional, dan kinerja karyawan pada PT Pancaputra Mitratama Mandiri dengan menggunakan pendekatan kuantitaif. Sumber data diperoleh melalui observasi, wawancara, dan kuisioner. PT Pancaputra Mitratama Mandiri berlokasi Jl. Kupang Indah 1 No.11, Sonokwijenan, Kota Surabaya, Jawa Timur. Teknik samplingnya adalah nonprobability sampling, dengan jenis purposive sampling dan pendekatan melalui judgement sampling. Populasi dalam penelitian ini yaitu segenap karyawan PT Pancaputra Mitratama Mandiri sebanyak 32 karyawan. Olah data menggunakan aplikasi SmartPLS 3.0 yang memakai pendekatan SEM dan PLS dengan skala Likert 1-5. 
Untuk mengukur kepemimpinan transformasional memakai indikator dari Bass dan Avolio dalam Antonakis (2012) yaitu terdiri dari karismatik, motivasi yang menginspirasi, stimulasi intelektual, dan konsiderasi individu. Indikator untuk mengukur perubahan organisasi dikembangkan oleh Methode et. al. (2019) yaitu perubahan struktur, perubahan strategis, dan perubahan teknologi. Variabel budaya organisasi dalam penelitian ini menggunakan indikator dari Denison dan Mishra (1995) yang terdiri dari keterlibatan, konsistensi, adaptabilitas, dan misi. Terakhir, untuk mengukur kinerja karyawan menggunakan indikator dari Rahman dan Kistyanto (2019) yaitu kuantitas dari hasil, kualitas dari hasil, ketepatan waktu dari hasil, dan kehadiran di tempat kerja.

\section{HASIL DAN PEMBAHASAN}

\section{Karakteristik Responden}

Data diperoleh melalui penyebaran kuisioner. Teknik sampling menggunakan non-probability sampling, dengan jenis purposive sampling dan pendekatan melalui judgement sampling yang melibatkan pilihan subjek yang paling menguntungkan atau posisi terbaik dalam memberikan informasi, yaitu sebanyak 19 dari 32 jumlah populasi. Karakteristik responden adalah berdasarkan usia, jenis kelamin, status, pendidikan terakhir, masa kerja, jabatan, dan departemen.

Karakteristik usia responden adalah 20-30 tahun adalah 8 orang $(42,1 \%), 31-40$ tahun yaitu 8 orang $(42,1 \%)$, dan 41-50 tahun ialah 3 orang $(15,8 \%)$. Dengan persentase jenis kelamin laki-laki adalah 15 orang $(78,9 \%)$ dan perempuan sebanyak 4 orang $(21,1 \%)$. Status responden penelitian ini adalah menikah sebanyak 17 orang $(89,5 \%)$ dan belum menikah sebanyak 2 orang (10,5\%). Pendidikan terakhir karyawan PT Pancaputra Mitratama Mandiri rata-rata adalah lulusan S1 sebanyak 10 orang $(52,6 \%)$, lulusan D3 sebanyak 3 orang (15,8\%), lulusan SLTA sebanyak 5 orang (26,3\%), dan lainnya sebanyak 1 orang $(5,3 \%)$. Persentase masa kerja responden adalah 5 bulan-1 tahun sebanyak 1 orang (5,3\%), 2-5 tahun sebanyak 10 orang (52,6\%), 6-10 tahun sebanyak 6 orang (31,6\%), dan 11-15 tahun sebanyak 2 orang (10,5\%). Karakteristik jabatan dalam penelitian ini adalah jabatan sales manager sebanyak 2 orang $(10,5 \%)$, HRD sebanyak 1 orang $(5,3 \%)$, DSR sebanyak 7 orang $(36,8 \%)$, KAE sebanyak 1 orang $(5,3 \%)$, house keeping sebanyak 2 orang (10,5\%), staff sebanyak 2 orang $(10,5 \%)$, business analysis sebanyak 1 orang (5,3\%), driver sebanyak 2 orang (10,5\%), dan admin accounting sebanyak 1 orang $(5,3 \%)$. Departemen responden di penelitian ini terdiri dari salesman sebanyak 10 orang $(52,6 \%)$, operasional sebanyak 5 orang $(26,3 \%)$, HRD sebanyak 1 orang $(5,3 \%)$, customer servive sebanyak 1 orang $(5,3 \%)$, business analysis sebanyak 1 orang $(5,3 \%)$, dan keuangan sebanyak 1 orang $(5,3 \%)$.

\section{Convergent Validity}

Masing-masing variabel memiliki nilai convergent validity yang baik yaitu $>0,50$ sehingga dapat dikatakan valid, hasil detail sesuai seperti gambar 2 di bawah ini.

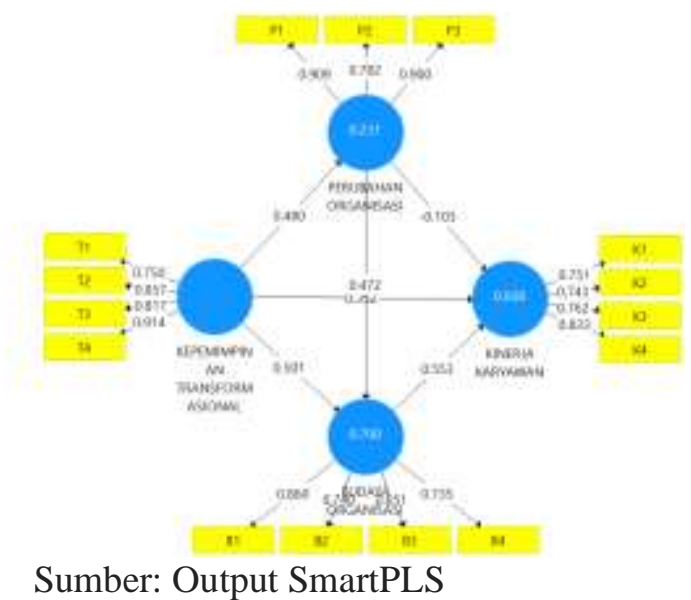

Gambar 2. MEASUREMENT MODEL 
Safira Shabrina. Hubungan antara Perubahan Organisasi, Budaya Organisasi, Kepemimpinan Transformasional, dan Kinerja Karyawan pada PT Pancaputra Mitratama Mandiri

\section{Composite Reliability dan Cronbach's Alpha}

Berdasarkan nilai composite reliability dan cronbach's alpha penelitian ini ialah >0,70, maka model variabel memiliki reliabilitas yang baik dan kuat.

Tabel 1.

COMPOSITE RELIABILITY DAN CRONBACH'S ALPHA

\begin{tabular}{ccc}
\hline Variabel & Composite Reliability & Cronbach's Alpha \\
\hline Kepemimpinan transformasional & 0,903 & 0,855 \\
Perubahan organisasi & 0,899 & 0,830 \\
Budaya Organisasi & 0,836 & 0,736 \\
Kinerja Karyawan & 0,856 & 0,775 \\
\hline
\end{tabular}

Sumber: Output SmartPLS

\section{R-Square}

Berdasarkan Tabel 2, R-square kepemimpinan transformasional terhadap budaya organisasi sebesar 0,700 atau $70 \%$, artinya kepemimpinan transformasional mampu menjelaskan budaya organisasi sebesar $70 \%$ dan sisanya sebesar 30\% dijelaskan oleh variabel di luar penelitian ini. Variabel kepemimpinan transformasional dapat menjelaskan kinerja karyawan sebesar 0,608 atau 60,8\% dan sisanya $39,2 \%$ dijelaskan variabel di luar penelitian ini. Variabel kepemimpinan transformasional mampu menjelaskan variabel perubahan organisasi sebesar 0,231 atau $23,1 \%$ dan dijelaskan sisanya $76,9 \%$ oleh variabel selain dalam penelitian ini.

Tabel 2.

\section{R-SQUARE MODEL}

\begin{tabular}{lc}
\hline \multicolumn{1}{c}{ Variabel } & R-Square \\
\hline Kepemimpinan & \\
transformasional & 0,700 \\
Budaya organisasi & 0,608 \\
Kinerja karyawan & 0,231 \\
Perubahan organisasi &
\end{tabular}

Sumber: Output SmartPLS

\section{Pengaruh Langsung dan Tidak Langsung}

Tabel 3 menjelaskan hasil hipotesis dilihat dari t-statistik dan original sample. H2, H3, dan $\mathrm{H} 6$ terbukti dalam penelitian ini, sedangkan $\mathrm{H} 1, \mathrm{H} 4, \mathrm{H} 5, \mathrm{H} 7$, dan $\mathrm{H} 8$ tidak terbukti dalam penelitian ini.

\section{Pengaruh Kepemimpinan Transformasional terhadap Kinerja Karyawan PT Pancaputra Mitratama Mandiri}

Sesuai dengan olah data, dapat diketahui bahwa kepemimpinan transformasional tidak berpengaruh secara signifikan terhadap kinerja karyawan, hal ini membuktikkan bahwa hipotesis pertama ditolak. Penelitian ini memperkuat hasil penelitian dari Yusuf (2015), kepemimpinan memiliki pengaruh tidak signifikan karena cenderung menurunkan kinerja karyawan. Berbeda dengan Kurniawan (2018) yang menerangkan bahwa kepemimpinan memengaruhi kinerja secara signifikan positif.

Hasil tidak signifikan ini dapat dijelaskan bahwa walaupun kepemimpinan dalam PT Pancaputra Mitratama Mandiri semakin baik ataupun semakin buruk, hal tersebut tidak memengaruhi peningkatan maupun penurunan kinerja karyawan PT Pancaputra Mitratama Mandiri. Melalui wawancara dan observasi awal dengan karyawan dikethui bahwa hubungan antara pemimpin dan karyawan sangat dekat dan akrab. Hal ini dikatakan pula oleh HRD PT Pancaputra Mitratama Mandiri bahwa tidak adanya kesenjangan jabatan antara pimpinan dengan karyawan di bawahnya. Baik saat di kantor atau saat jam kerja, maupun saat di luar kantor kekompakan dan kedekatan itu masih terjaga. Namun, rupanya kedekatan di dalam organisasi ini tidak memberikan pengaruh dalam kinerja karyawan. 
Tabel 3.

PENGARUH LANGSUNG DAN TIDAK LANGSUNG

\begin{tabular}{|c|c|c|c|}
\hline Variabel & OS & T-statistik & Keterangan \\
\hline $\begin{array}{l}\text { Kepemimpinan transformasional } \\
\rightarrow \text { Kinerja karyawan }\end{array}$ & 0,352 & 1,035 & H1 Ditolak \\
\hline $\begin{array}{l}\text { Kepemimpinan transformasional } \\
\rightarrow \text { Perubahan organisasi }\end{array}$ & 0,480 & 2,634 & H2 Diterima \\
\hline $\begin{array}{l}\text { Kepemimpinan transformasional } \\
\rightarrow \text { Budaya organisasi }\end{array}$ & 0,501 & 2,772 & H3 Diterima \\
\hline $\begin{array}{l}\text { Perubahan organisasi } \rightarrow \text { Kinerja } \\
\text { karyawan }\end{array}$ & $-0,103$ & 0,283 & H4 Ditolak \\
\hline $\begin{array}{l}\text { Budaya organisasi } \rightarrow \text { Kinerja } \\
\text { karyawan }\end{array}$ & 0,553 & 1,257 & H5 Ditolak \\
\hline $\begin{array}{l}\text { Perubahan organisasi } \rightarrow \text { Budaya } \\
\text { organisasi }\end{array}$ & 0,472 & 2,457 & H6 Diterima \\
\hline $\begin{array}{l}\text { Kepemimpinan transformasional } \\
\rightarrow \text { Kinerja karyawan } \rightarrow \text { Budaya } \\
\text { Organisasi }\end{array}$ & 0,226 & 1,689 & H7 Ditolak \\
\hline $\begin{array}{l}\text { Kepemimpinan transformasional } \\
\rightarrow \text { Kinerja karyawan } \rightarrow \text { Perubahan } \\
\text { organisasi }\end{array}$ & 0,353 & 1,228 & H8 Ditolak \\
\hline $\begin{array}{l}\text { Perubahan organisasi } \rightarrow \text { Kinerja } \\
\text { karyawan } \rightarrow \text { Budaya organisasi }\end{array}$ & 0,261 & 1,030 & H9 Ditolak \\
\hline
\end{tabular}

Wawancara dengan karyawan menunjukkan hasil bahwa keputusan yang diambil pimpinan dirasa kurang menguntungkan bagi kedua belah pihak yaitu pimpinan dan bawahan, sehingga dampak keputusan tersebut memengaruhi kinerja karyawan PT Pancaputra Mitratama Mandiri. Indikator karismatik mampu menjadi indikasi kekurangan dari kepemimpinan PT Pancaputra Mitratama Mandiri terhadap kinerja karyawan. Indikator karismatik di definisikan bagaimana karyawan menghormati, mengagumi, dan mempercayai pimpinan. Kedekatan antara pimpinan dan karyawan rupanya tidak selalu menjanjikan hasil kinerja yang maksimal. Sehingga, perlunya evaluasi pengambilan keputusan agar dapat terjamin kesejahteraan dan keuntungan yang rata antara pimpinan dan karyawan PT Pancaputra Mitratama Mandiri sehingga mampu meningkatkan kinerja karyawannya.

\section{Pengaruh Kepemimpinan Transformasional terhadap Perubahan Organisasi PT Pancaputra Mitratama Mandiri}

Pengolahan data menyatakan bahwa antara kepemimpinan transformasional terhadap perubahan organisasi menunjukkan hipotesis kedua diterima atau ada pengaruh secara signifikan positif antara kepemimpinan transformasional di PT Pancaputra Mitratama Mandiri terhadap perubahan organisasi di PT Pancaputra Mitratama Mandiri.

Penelitian ini menyetujui teori dari Utami (2007), bahwa diperlukan kepemimpinan yang kuat dari segi kepribadian dan komitmen agar mampu terlaksana perubahan dalam organisasi. Perubahan dalam struktur organisasi seperti penambahan departemen, perubahan teknologi, dan perubahan strategi yang telah dilalui PT Pancaputra Mitratama Mandiri tentu tidak mudah dan instan. Pemimpin perlu waktu untuk adaptasi, pengujian, dan penyesuaian dengan karyawan agar pelaksanaan perubahan dapat terlaksana dengan sempurna. Artinya, pemimpin PT Pancaputra Mitratama Mandiri dengan kepemimpinan transformasionalnya telah berhasil dan secara baik melakukan perubahan budaya, perubahan struktur organisasi, dan perubahan teknologi yaitu pembuatan aplikasi untuk mempermudah tim sales menginput hasil kerjanya dan bisa dimonitor langsung oleh pimpinan PT Pancaputra Mitratama Mandiri. 
Safira Shabrina. Hubungan antara Perubahan Organisasi, Budaya Organisasi, Kepemimpinan Transformasional, dan Kinerja Karyawan pada PT Pancaputra Mitratama Mandiri

\section{Pengaruh Kepemimpinan Transformasional terhadap Budaya Organisasi PT Pancaputra Mitratama Mandiri}

Penelitian ini membuktikan pengaruh variabel kepemimpinan transformasional terhadap budaya organisasi. Temuan ini memperkuat penelitian dari Kartini dan Rustanto (2018), kepemimpinan memengaruhi secara signifikan positif terhadap budaya organisasi di Politeknik LP3I, Jakarta. Sebaliknya, Riski et. al. (2014) menjelaskan bahwa kepemimpinan transformasional tidak memiliki pengaruh terhadap budaya organisasi CV. Muse Entertainment Center Samarinda.

Variabel kepemimpinan transformasional nyatanya memiliki pengaruh yang tinggi terhadap budaya organisasi di PT Pancaputra Mitratama Mandiri dalam penelitian ini, salah satunya indikator motivasi yang menginspirasi memiliki nilai yang paling tinggi mampu membentuk budaya yang baik dalam meningkatkan efektivitas organisasi. Contohnya, adalah indikator keterlibatan dari karyawan yang didorong oleh pimpinan PT Pancaputra Mitratama Mandiri agar mampu inovatif dan berani mengambil resiko. Indikator misi yang ditekankan oleh pimpinan yaitu pertimbangan-pertimbangan keputusan terhadap kendala dari karyawan agar mampu menyelesaikan permasalahan kerjanya setiap briefing meeting, budaya baru ini menjadi solutif bagi kinerja karyawan PT Pancaputra Mitratama Mandiri.

\section{Pengaruh Perubahan Organisasi terhadap Kinerja Karyawan PT Pancaputra Mitratama Mandiri}

Perubahan organisasi tidak berpengaruh secara signifikan terhadap kinerja karyawan atau hipotesis keempat ditolak. Penelitian ini sama seperti penelitian terdahulu yang menyatakan perubahan organisasi tidak memengaruhi terhadap kinerja karyawan secara signifikan (Hasanah dan Aima, 2018). Berbeda dengan penelitian dari Poluakan (2016) yang menyatakan adanya perubahan di organisasi berpengaruh signifikan positif terhadap kinerja karyawan KPKNL Banjarmasin. Hasil pengaruh yang tidak signifikan ini dapat didefinisikan perubahan apapun yang diterapkan PT Pancaputra Mitratama Mandiri tidak akan memberikan dampak atau pengaruh dalam kinerja karyawan PT Pancaputra Mitratama Mandiri. Item pernyataan perusahaan ini menghilangkan posisi rangkap pada karyawan saat perubahan organisasi dapat menjadi indikasi penyebab perubahan di PT Pancaputra Mitratama Mandiri tidak memengaruhi kinerja karyawan.

Berdasarkan wawancara awal dengan karyawan PT Pancaputra Mitratama Mandiri, ada beberapa divisi yang perlu mengerjakan pekerjaan rangkap karena pimpinan merasa pekerjaan tersebut bisa dikerjakan dan diselesaikan oleh karyawan tertentu, namun nyatanya pekerjaan tambahan ini terasa berat apabila harus dipikul dengan pekerjaan inti dan mampu mengurangi efektivitas kerja. Perubahan struktur dalam organisasi yaitu penambahan divisi sudah pernah terlaksana sebelumnya dan hal ini berdampak banyak terkait pertumbuhan organisasi, sehingga pimpinan perlu mempertimbangkan penambahan divisi terkait kasus pekerjaan yang tumpang tindih agar dapat meningkatkan kinerja antar divisi dan meringankan beban pekerjaan karyawan agar lebih fokus sesuai pada jobdesc.

\section{Pengaruh Budaya Organisasi terhadap Kinerja Karyawan PT Pancaputra Mitratama Mandiri}

Uji t-statistik antara budaya organisasi terhadap kinerja karyawan adalah tidak berpengaruh secara signifikan sehingga hipotesis kelima ditolak. Penelitian ini menyetujui hasil penelitian dari Hasanah dan Aima (2018), budaya organisasi tidak berpengaruh signifikan terhadap kinerja karyawan, sebab bukan prioritas utama dalam peningkatan kinerja pada pegawai Badan Manajemen PPPIJ. Pengaruh yang tidak signifikan artinya sebaik atau seburuk apa budaya di PT Pancaputra Mitratama Mandiri tidak akan ada pengaruhnya dalam kenaikan dan penuruan kinerja karyawan PT Pancaputra Mitratama Mandiri. Sebaliknya, Sagita et. al., (2018) menjelaskan bahwa budaya organisasi berpengaruh signifikan positif terhadap kinerja karyawan PT Astra Internasional.

Berdasarkan wawancara awal dengan karyawan PT Pancaputra Mitratama Mandiri terutama tim sales, fokus dari karyawan adalah menjual produk Shell sesuai dengan target yang ditetapkan oleh Shell pusat setiap harinya. Kegiatan yang dilaksanakan di kantor hanya divisi tertentu sedangkan tim sales akan menuju berbagai tempat untuk menjual produk secara individual. Terkadang, pemahaman dan penanaman budaya dalam perusahaan kurang terintepretasikan sebab karyawan akan bekerja secara 
individu, sebab tanggung jawab dan target dipikul secara personal. Oleh karenanya, bukan budaya yang menjadi prioritas utama PT Pancaputra Mitratama Mandiri dalam peningkatan kinerja karyawannya.

\section{Pengaruh Perubahan Organisasi terhadap Budaya Organisasi PT Pancaputra Mitratama Mandiri}

Hasil pengujian menunjukkan bahwa perubahan organisasi berpengaruh signifikan positif terhadap budaya organisasi atau hipotesis 6 diterima. Penelitian ini memperkuat penelitian dari Fahrudin et. al. (2019), perubahan organisasi berpengaruh signifikan positif terhadap budaya organisasi.

Perubahan yang terjadi di PT Pancaputra Mitratama Mandiri memengaruhi budaya pada organisasi. Berdasarkan wawancara dengan HRD dan juga observasi awal, konsistensi karyawan yaitu perihal fokus kepada hal rinci, analisis, dan kecermatan yang dilaksanakan tim sales pada saat briefing meeting mampu melatih tim sales lebih teliti dan kritis saat menyelesaikan tugasnya.

Item pernyataan perubahan organisasi yaitu perusahaan ini memertimbangkan budaya dan kebiasaan karyawannya sebelum mengimplementasikan perubahan memiliki arti pimpinan melihat perlunya perubahan budaya sebab sebelumnya PT Pancaputra Mitratama Mandiri tidak mempertimbangkan penanaman budaya yang baik di perusahaan. Perubahan yang disusun oleh pimpinan ini memberikan dampak yang positif dalam implementasi budaya di PT Pancaputra Mitratama Mandiri.

\section{Pengaruh Kepemimpinan Transformasional terhadap Kinerja Karyawan melalui Budaya} Organisasi PT Pancaputra Mitratama Mandiri

Hasil pengujian total indirect effect untuk melihat mediasi antar variabel diketahui bahwa budaya organisasi tidak memediasi hubungan kepemimpinan transformasional terhadap kinerja karyawan atau hipotesis 7 ditolak.

Dapat diartikan bahwa variabel kepemimpinan transformasional di PT Pancaputra Mitratama Mandiri terhadap kinerja karyawan PT Pancaputra Mitratama Mandiri tidak dipengaruhi atau dibantu oleh variabel budaya organisasi. Berdasarkan wawancara dengan karyawan PT Pancaputra Mitratama Mandiri, budaya di PT Pancaputra Mitratama Mandiri bukanlah prioritas utama perusahaan untuk meningkatkan kinerja karyawan, disebabkan tingginya kerja secara individual karyawan sesuai target dan kurang memperhatikan budaya perusahaan. Sedangkan, pemimpin PT Pancaputra Mitratama Mandiri kurang mampu memberikan pengaruh karismatiknya terhadap kinerja karyawan. Kedua variabel ini sama-sama tidak memberikan pengaruh terhadap kenaikan maupun penuruan kinerja.

\section{Pengaruh Kepemimpinan Transformasional terhadap Kinerja Karyawan melalui Perubahan Organisasi PT Pancaputra Mitratama Mandiri}

Nilai total indirect effect pengaruh dari kepemimpinan transformasional terhadap kinerja karyawan melalui perubahan organisasi hasilnya adalah tidak signifikan dan hipotesis 8 ditolak. Kepemimpinan transformasional pimpinan di PT Pancaputra Mitratama Mandiri tidak berpengaruh terhadap kinerja apabila melalui perubahan organisasi. Perubahan yang dilakukan PT Pancaputra Mitratama Mandiri tidak membantu variabel kepemimpinan transformasional dalam meningkatkan atau menurunkan kinerja karyawan PT Pancaputra Mitratama Mandiri. Berdasarkan wawancara dengan karyawan PT Pancaputra Mitratama Mandiri menunjukkan perubahan yang terjadi di perusahaan telah berjalan secara baik dari segi stuktur, strategi, dan teknologi. Namun, terdapat aspek perubahan dari pemimpin yang kurang berjalan baik yaitu item pernyataan perusahaan ini menghilangkan posisi rangkap pada saat perubahan terjadi yang menjadi indikasi keputusan pemimpin terhadap perubahan struktur menjadi kesalahan tidak berpengaruhnya kedua variabel tersebut terhadap kinerja karyawan PT Pancaputra Mitratama Mandiri. Posisi rangkap ini mampu merugikan divisi tertentu karena kurangnya efisiensi dalam menyelesaikan kerjanya.

\section{Pengaruh Perubahan Organisasi terhadap Kinerja Karyawan melalui Budaya Organisasi PT Pancaputra Mitratama Mandiri}


Safira Shabrina. Hubungan antara Perubahan Organisasi, Budaya Organisasi, Kepemimpinan Transformasional, dan Kinerja Karyawan pada PT Pancaputra Mitratama Mandiri

Pengujian total indirect effect variabel perubahan organisasi terhadap kinerja karyawan melalui budaya organisasi adalah tidak signifikan dan hipotesis 9 ditolak. Hasil ini menunjukkan bahwa perubahan pada PT Pancaputra Mitratama Mandiri tidak memengaruhi kinerja karyawan PT Pancaputra Mitratama Mandiri apabila dimediasi oleh budaya organisasi. Budaya organisasi tidak membantu perubahan organisasi untuk meningkatkan atau menurunkan kinerja karyawan PT Pancaputra Mitratama Mandiri. Hasil kuisioner item pernyataan budaya organisasi perusahaan ini sangat responsif dan mudah berubah, memiliki nilai sedang yang menyatakan PT Pancaputra Mitratama Mandiri masih perlu meningkatkan kepekaan terutama aspek perubahan di lingkungannya agar mampu meningkatkan kinerja karyawan dan menjadi perusahaan yang kuat dan mampu bersaing dengan kompetitor.

\section{KESIMPULAN}

Berdasarkan hasil pengujian terhadap hipotesis, dapat diketahui hubungan antara variabel kepemimpinan transformasional, perubahan organisasi, dan budaya organisasi tidak berpengaruh signifikan terhadap kinerja karyawan PT Pancaputra Mitratama Mandiri. Kedua, kepemimpinan transformasional berpengaruh signifikan positif terhadap perubahan organisasi dan juga budaya organisasi di PT Pancaputra Mitratama Mandiri. Ketiga, perubahan organisasi berpengaruh signifikan positif terhadap budaya organisasi PT Pancaputra Mitratama Mandiri. Keempat, budaya organisasi tidak memediasi hubungan kepemimpinan transformasional terhadap kinerja karyawan PT Pancaputra Mitratama Mandiri. Kelima, perubahan organisasi tidak memediasi hubungan kepemimpinan transformasional terhadap kinerja karyawan PT Pancaputra Mitratama Mandiri. Terakhir, budaya organisasi tidak memediasi hubungan perubahan organisasi terhadap kinerja karyawan PT Pancaputra Mitratama Mandiri.

Saran yang dapat diberikan kepada perusahaan adalah pimpinan PT Pancaputra Mitratama Mandiri seharusnya mampu lebih memperhatikan karyawannya agar kebutuhannya dapat terpenuhi dan bisa meningkatkan kinerja, misalnya menggencarkan pelatihan demi peningkatan kompetensi karyawan dan mendengar maupun menanggapi keluh kesah hingga saran yang diberikan karyawan, walau perubahan telah terlaksana di PT Pancaputra Mitratama Mandiri, perlu adanya evaluasi rutin terhadap perubahan apa saja yang sudah terlaksana dan yang seharusnya dilaksanakan di masa depan agar perusahaan mampu tetap bersaing di dunia industri. Berdasarkan hasil semua variabel yang memengaruhi kinerja, hasilnya keseluruhan adalah tidak signifikan. Dapat diartikan bahwa ada variabel lain yang mampu memperbaiki kinerja karyawan di PT Pancaputra Mitratama Mandiri, sehingga saran untuk penelitian selanjutnya adalah meneliti lebih lanjut tentang pemberian insentif, sistem reward dan punishment, dan juga variabel pelatihan dan pengembangan terhadap kinerja karyawan.

\section{DAFTAR PUSTAKA}

Akbar, M.A. and Boseren, M. (2016), "Pengaruh Budaya Organisasi, Gaya Kepemimpinan dan Kompetensi terhadap Kinerja Pegawai Balai Laboratorium Kesehatan Papua”, Jurnal Future Jurnal Manajemen Dan Akuntansi, Vol. 3 No. 2, pp. 242-252.

Antonakis, J. (2012), Transformational and Charismatic Leadership, The Nature of Leadership, Vol. 41, available at:https://doi.org/10.1016/j-leaqua.2012.05.002.

Denison, D.R. and Mishra, A.K. (1995), "Toward a Theory of Organizational Culture and Effectiveness", Organization Science, Vol. 6 No. 2, pp. 204-223.

Fahrudin, V., Nurwati and Saleh, S. (2019), "Pengaruh Perubahan Organisasi pada Kinerja Pegawai dengan Budaya Organisasi Sebagai Variabel Mediasi”, JUMBO (Jurnal Manajemen, Bisnis Dan Organisasi), Vol. 2 No. 2, pp. 25-32.

Gholamzadeh, D., Tahvildar Khazaneh, A. and Salimi Nabi, M. (2014), "The Impact of Leadership 
Styles on Organizational Culture in Mapsa Company”, Management Science Letters, Vol. 4 No. 9, pp. 2161-2170.

Hasanah, R.U. and Aima, M.H. (2018), "Pengaruh Perubahan Organisasi, Budaya Organisasi Dan Motivasi Terhadap Kinerja Pegawai Badan Manajemen Pusat Pengkajian Dan Pengembangan Islam Jakarta", INDIKATOR (Jurnal Ilmiah Manajemen \& Bisnis), Vol. 2.

İkinci, S.S. (2014), "Organizational Change: Importance of Leadership Style and Training", Management and Organizational Studies, Vol. 1 No. 2, pp. 122-128.

Ismail, I. (2017), "Pengaruh Budaya Organisasi Terhadap Kepemimpinan Dan Kinerja Karyawan Pemerintah Kabupaten-Kabupaten Di Madura", EKUITAS (Jurnal Ekonomi Dan Keuangan), Vol. 12 No. 1, p. 18.

Kartini, I. and Rustanto, A.E. (2018), "Pengaruh Budaya Organisasi Terhadap Kinerja Karyawan Di Politeknik LP3I Jakarta", Jurnal Lentera Bisnis, Vol. 7 No. 2, p. 1.

Kristanti, J. (2011), Pengaruh Kepemimpinan Dan Manajemen Perubahan Terhadap Budaya Organisasi Dan Kompetensi Karyawan PTPN XII Kebun Kendeng Lembu Glenmore Banyuwangi, Skripsi, Jember: Universitas Jember.

Kurniawan, M. (2018), "Pengaruh Gaya Kepemimpinan Terhadap Kinerja Karyawan Percetakan Dimas Kota Palembang”, Jurnal Ilmiah Manajemen Bisnis Dan Terapan, No. 1, pp. 33-48.

Methode, K., Osunsan, O.K., Florence, I., Augustine, W., Abiria, P. and Innocent, B. (2019), "Effect of Organizational Change on Employee Performance among selected Commercial Banks in Bujumbura , Burundi .", East African Scholars Journal of Economics, Business and Management, Vol. 2 No. 4.

Poluakan, F.A. (2016), "Pengaruh Perubahan dan Pengembangan Organisasi terhadap Kinerja Karyawan PT. Sinar Galesong Prima Manado", Jurnal EMBA, Vol. 4 No. 3, pp. 1057-1067.

Priyono, B.S., Sutomo, Y., Rijanti, T., Farokhi, A.H. and Kuncoro, A. (2018), "The Influence of Psychological Capital and Organizational Change to Employee Performance with Organizational Commitment as Moderating Variable", International Journal of Human Resource Studies, Vol. 8 No. 4, p. 84.

Raharjo, S.T. and Nafisah, D. (2006), “Analisis Pengaruh Gaya Kepemimpinan Terhadap Kepuasan Kerja, Komitmen Organisasi dan Kinerja Karyawan (Studi Empiris Pada Departemen Agama Kabupaten Kendal dan Departemen Agama Kota Semarang)", Jurnal Studi Manajemen Dan Organisasi, Vol. 3 No. 2, pp. 69-81.

Rahman, M.F.W. and Kistyanto, A. (2019), "Hubungan antara Iklim Psikologis terhadap Kinerja Karyawan melalui Kepuasan Kerja", Dinamika Ekonomi Jurnal Ekonomi Dan Bisnis, Vol. 12 No. 2, pp. 410-429.

Riski, R.M., Rosliana, L. and Muzayannah, H.A. (2014), "Pengaruh Kepemimpinan Transformasional terhadap Budaya Organisasi pada Karyawan CV. Muse Entertainment Center Samarinda", Jurnal MOTIVASI, pp. 1-22.

Riyono, B. (2015), "Kepemimpinan Transformasional Kebangkitan Kembali Studi Tentang Kepemimpinan", Buletin Psikologi, Vol. 7 No. 1, pp. 28-34.

Robbins, S.P. and Judge, T.A. (2015), Perilaku Organisasi (Organizational Behavior 16th Edition), McGraw Hill dan Salemba Empat, Jakarta. 
Safira Shabrina. Hubungan antara Perubahan Organisasi, Budaya Organisasi, Kepemimpinan Transformasional, dan Kinerja Karyawan pada PT Pancaputra Mitratama Mandiri

Sagita, A.A., Susilo, H. and Cahyo WS, M. (2018), "Pengaruh Budaya Organisasi Terhadap Kinerja Karyawan Dengan Motivasi Kerja Sebagai Variabel Mediator (Studi Pada PT Astra Internasional, Tbk-Toyota (Auto2000) Cabang Sutoyo Malang)", Jurnal Administrasi Bisnis $(J A B)$, Vol. 57 No. 1.

Septyan, F.B., Musadieq, M. Al and Mukzam, M.D. (2017), "Pengaruh Gaya Kepemimpinan Transformasional terhadap Motivasi dan Kinerja (Studi pada Karyawan CV. Jade Indopratama Malang)", Jurnal Administrasi Bisnis (JAB), Vol. 53 No. 1, pp. 81-88.

Sunaryo. (2017), "Pengaruh Perubahan Organisasi, Budaya Organisasi Dan Perilaku Kerja Terhadap Kinerja Karyawan Di PT. Sisirau Medan”, Jurnal Ilmiah Manajemen Dan Bisnis, Vol. 18 No. 1, pp. 101-114.

Utami, A.B., Wibowo, E. and Utami, S.S. (2017), "Pengaruh kepemimpinan, budaya organisasi, dan profesionalisme terhadap kinerja dengan kepuasan kerja sebagai variabel moderasi", Jurnal Manajemen Sumber Daya Manusia, Vol. 11 No. 1, pp. 108-120.

Utami, S.S. (2007), "Pengaruh Kepemimpinan dalam Perubahan Organisasi”, Jurnal Ekonomi Dan Kewirausahaan, Vol. 3 No. 1, pp. 149-157.

Wanza, L. and Nkuraru, J.K. (2016), "Influence of Change Management on Employee Performance: A Case of University of Eldoret, Kenya Sr . Lucy Wanza Catholic University of Eastern Africa Catholic University of Eastern Africa”, International Journal of Business and Social Science, Vol. 7 No. 4, pp. 190-199.

Yusthisia, A.B. (2019), "Analisis Implementasi Manajemen Perubahan terhadap Kepemimpinan dan Budaya Kerja Serta Pengaruhnya Pada Kinerja Karyawan Di Bank Jatim Cabang Banyuwangi”, Journal of Chemical Information and Modeling, Vol. 53 No. 9, pp. 1689-1699.

Yusuf, M. (2015), "Pengaruh Gaya Kepemimpinan Dan Budaya Organisasi Terhadap Kepuasan Kerja Dan Kinerja Guru Militer Resimen Induk Komando Daerah Militer VII/Wirabuana Di Sulawesi”, Jurnal Bisnis Dan Kewirausahaan, Vol. 5, pp. 219-236. 